\title{
Sociodemographic indicators and quality of life of caregivers of children with neuromotor changes
}

\author{
Neide Maria Gomes de Lucena', Patrícia Meireles Brito², Rafaela Vitória Pereira Felipe², Eliene Martins de Lira³, \\ Natália Gonçalves de Lira², Susana Lígia da Silva Rodrigues², Maria de Fátima Alcântara Barros', \\ Antônio Geraldo Cidrão de Carvalho', Maria das Graças Rodrigues de Araújo4
}

\begin{abstract}
Introduction: Children with neuromotor changes are challenged daily, and such challenges may be faced with the help of a caregiver. Thus, the functional dependence of these children lead to the daily demands, causing physical and emotional distress, which affect the quality of life of their caregiver. Objective: Analyze the sociodemographic indicators that interfere with the level of life quality of the caregivers of children with neuromotor changes. Method: 50 caregivers of children with neuromotor changes were interviewed at the Association of Parents and Friends of the Exceptional (APAE) of Paraiba, on the city of João Pessoa. To evaluate the quality of life, the questionnaire SF-36 was used, in addition to collecting demographic data (sex, age, degree of kinship, marital status, number of children, school level and religion). For the data analysis, a descriptive study was developed, the normality test of Shapiro-Wilk was realized, followed by the inferential analysis with non-parametric correlation of Spearman, considering the significant value $\alpha=0.05$. Results: There was a predominance of the female sex (96\%) with medium age of $\geq 39$ years old. Correlating the sociodemographic indicators with the level of life quality of the SF-36 of the caregivers, only the vitality domain presented significance with the variables: number of children $(p=0.012)$, benefits $(p=0.044)$, and how the transfer of the child is done $(p=0.044)$. There was no significant difference relating the sociodemographic indicators on the other domains. Conclusion: The knowledge of sociodemographic indicators that interfere with the quality of life shows the importance of preventive measures, such as guidance and, if needed, treatment for improvement of possible grievances.
\end{abstract}

Key-Words: Caregiver, Overload, Quality of Life.

\section{INTRODUCTION}

The neuromotor disorder relate to the disorder on the control of posture and movement, caused by lesion on the central nervous system. The neurological lesions occurred on childhood may lead to muscular, articular, orthopedic or cognitive damage, that may difficult the development of the individual in the growth phase, the sequelae can last a lifetime. Children with neuromotor changes are challenged daily, and such challenges can be faced with the help of a caregiver. ${ }^{(1)}$ It's in the context of the daily demands, physical and psychological, faced by the disabled person that comes the role of the caregiver.

The caregiver can be defined as the individual whose mission is the care with life and with the similar, which proposes devoting time. It can then include resignations, responsibilities, involvement with suffering and believing in the success of life. This public implies: Mother, father, grandfather or any other person exercising this role. ${ }^{(2)}$
The functional dependence of the disabled child implies to the caregiver the concern and the constant care that causes overload, and physical and emotional wear, especially for mothers, which assume the care of the child with frequency. The tasks of feeding, hygiene and transportation of the child are the factors that require more physical effort of the mothers. ${ }^{(3,4)}$

The concept of quality of life is related to the personal well-being, covering a series of aspects, such as functional capability, socioeconomic level, emotional state, social interaction, intellectual activity, self-care, family support, health status, cultural and ethical values, and religion. ${ }^{(5)}$ In human history, care is related to survival, reflected in health and, consequently, quality of life. On this context, family is the basic support unity to all those that need care. ${ }^{(6)}$

The act of caring relates to life quality since the caregiver experiences diverse situations in the family, like financial, 
exercise of family roles, feelings of helplessness, loss of control, exclusion and overload, as well as factors that can lead to stress. ${ }^{(7)}$

Thus, the aim of this study was to characterize the sociodemographic profile of caregivers of children with neuromotor changes, as well as to identify domains with the greatest decrease in quality of life. Correlating the sociodemographic variables with the level of quality of life.

\section{METHOD}

We conducted a cross-sectional study of the analytical type, with caregivers attending the Association of Parents and Friends of the Exceptional (APAE/PB), located in the city of João Pessoa, from September 2014 to March 2015. In this period 50 caregivers of both genders were interviewed, these caregivers aided children with neuromotor changes and voluntarily participated in the present study.

Study participants were casually identified by researchers from their medical records and addressed to the waiting room before or after the completion of treatment. The objectives and procedures of the study were presented, and the participants were asked to sign the informed consent, as required by CNS resolution no. 466/2012. By consent of the participants, they were led to a private room for them to be applied instruments used in the study, by two students of the Institutional Program for Scientific Initiation Scholarships (PIBIC), from the Federal University of Paraíba (UFPB), linked to the CNPq.

An inclusion criteria was adopted: family and/or guardians aged over 18 years; be the primary caregiver of a child diagnosed with any neuromotor change and provide care to the child for more than two months.

For the sociodemographic profile analysis, we used the sociodemographic questionnaire ${ }^{(6)}$, and assessed the data of the caregivers (gender, age, contact, profession/occupation, marital status, religion, family income, how many hours of caregiving/day, how many times a week, kinship with the child, age of the child, number of children, health habits, receiving of benefits and means of transportation to take the child to the institution).

To evaluate the quality of life of the caregivers, we used the questionnaire called Medical Outcomes Study 36-item Short Form Health Survey (SF-36). The SF-36 is a generic questionnaire made to assess quality of life, translated and adapted for the Brazilian population. ${ }^{(8)}$ The SF-36 is composed of thirty-six questions, grouped into eight domains: Functional Capability, Physical aspects, Pain, General state of health, Vitality, Social aspects, Emotional aspects and mental health. Scores range from 0 to 100 , in which zero corresponds to the worst general state and 100 to the perception of the best life quality related to health. ${ }^{(9,10)}$

The statistical analysis was carried out initially by using descriptive statistics (percentage frequency for each variable, calculating the mean and standard deviation). Then the variables were analyzed for normality (Shapiro-Wilk test).
Only four of the seventeen variables showed a normal distribution $(\alpha \geq 0.05)$. For inferential analysis, we used the nonparametric Spearman correlation, adopting the significance level of $p<0.05$. Analyses were performed using the software SPSS version 20.0 and Excel, for making graphs and charts.

The research project was submitted and approved by the Ethics Committee on Human Research of the University Hospital Lauro Wanderley of the Federal University of Paraíba (CAAE: 03808312.0.0000.5183).

\section{RESULTS}

The sample was composed of 50 caregivers of children with neuromotor changes with different diagnoses, chosen randomly. The caregivers were female $(96 \%)$, with age $\geq 39$ (96\%), mothers (94\%), married (64\%), had two children (46\%), finished second degree (High School) (36\%) and were catholic (74\%). As for family income, $84 \%$ received up to 2 minimum salaries. $62 \%$ of the caregivers declared they didn't receive any kind of benefits and, in addition, declare themselves as sedentary (70\%). As to the child dedication time, 38 caregivers $(76 \%)$ dedicate all the duration of the day to assist the child. (Table 1).

Regarding the type of transportation used, $44 \%$ of the caregivers use the family car as the mean of transportation. $24 \%$ of the caregivers that use the family car partially aid the child. Among the caregivers that use public transportation $(38 \%)$, more than half (20\%) partially aid the child. The aid is related to the transfer of the child, which refers to handling of daily activities as, for example, bathing, dressing, feeding, and assisting on the displacement from a place to another, among others (Table 2).

Regarding to the quality of life of the caregivers, of a total of 100 scores, an average global score of 64.9 was observed. The domains that presented the higher average score were: Functional Capability $=79.0$, Social Aspects $=65.4$, Limitation by emotional aspects $=71.3$ and Mental health $=67.3$ (Table 3 ).

Correlating the quality of life with the sociodemographic indicators of the caregivers, the variables "number of children", "benefits" and "how the transfer of the child is done" obtained a significant correlation with the vitality domain of the SF-36, according to table 4 .

\section{DISCUSSION}

The caregiver's overload can be conceptualized as a biopsychosocial sphere resulting from the search for a balance between the following variables: time available for care, financial, psychological, physical and social conditions, functions and distribution of roles. ${ }^{(11)}$ Thus, according to the data analyzed, it may be noted that most caregivers are mothers, whose role in society is subject to responsibilities like housework, besides taking care of their children. The results of this study were similar to those of Mugno (2007) ${ }^{(12)}$ in which a prevalence of mothers was also found (97.8\%). Studies 
Table 1. Sociodemographic profile of the caregivers of children with neuromotor changes seen at APAE/PB. Paraíba. 2015

\begin{tabular}{|c|c|c|}
\hline Variables & $n=50$ & $\%$ \\
\hline \multicolumn{3}{|l|}{ Gender } \\
\hline Female & 48 & 96 \\
\hline Male & 02 & 04 \\
\hline \multicolumn{3}{|l|}{ Age (years) } \\
\hline$<39$ & 02 & 04 \\
\hline$\geq 39$ & 48 & 96 \\
\hline \multicolumn{3}{|l|}{ Family Relationship } \\
\hline Mother & 47 & 94 \\
\hline Others & 03 & 06 \\
\hline \multicolumn{3}{|l|}{ Marital Status } \\
\hline Married & 32 & 64 \\
\hline Single & 09 & 18 \\
\hline Divorced & 06 & 12 \\
\hline Others & 03 & 06 \\
\hline \multicolumn{3}{|l|}{ Number of Children } \\
\hline 1 to 2 & 23 & 46 \\
\hline$\geq 3$ & 37 & 54 \\
\hline \multicolumn{3}{|l|}{ Level of Education } \\
\hline Primary School & 06 & 12 \\
\hline High School & 18 & 36 \\
\hline Higher Education & 02 & 04 \\
\hline \multicolumn{3}{|l|}{ Religion } \\
\hline Catholic & 37 & 74 \\
\hline Others & 13 & 26 \\
\hline \multicolumn{3}{|c|}{ Family Income (Num. of minimum salaries) } \\
\hline$<1$ & 21 & 42 \\
\hline 1 to 2 & 21 & 42 \\
\hline$>2$ & 08 & 16 \\
\hline \multicolumn{3}{|l|}{ Receiving Benefits } \\
\hline Yes & 19 & 38 \\
\hline No & 31 & 62 \\
\hline \multicolumn{3}{|l|}{ Time of dedication (hours/day) } \\
\hline Duration of the day & 38 & 76 \\
\hline Less than the duration of the day & 12 & 24 \\
\hline \multicolumn{3}{|l|}{ Habits of Life } \\
\hline Sedentary & 35 & 70 \\
\hline Not sedentary & 15 & 30 \\
\hline \multicolumn{3}{|l|}{ Type of locomotion transport } \\
\hline Own car & 22 & 44 \\
\hline Public car & 19 & 38 \\
\hline Other means of transportation & 09 & 18 \\
\hline
\end{tabular}

Table 2. Means of transfer and the need to aid the child. Paraíba 2015

\begin{tabular}{lcc}
\hline \multicolumn{1}{c}{ Means of transfer } & $\begin{array}{c}\text { Public } \\
\text { Transportation } \\
\text { (\%) }\end{array}$ & Family Car (\%) \\
\hline Fully assist the child & 4 & 12 \\
Partialy assist the child & 20 & 24 \\
The child doesn't need assistance & 14 & 08 \\
Total & 38 & 44 \\
\hline
\end{tabular}

conducted with mothers of children with cerebral paralysis (CP) some behaviors were observed: unwillingness to carry out physical activities and social relationships, poor health perception, lack of knowledge about the child's disease, decreased mood and problems in social life, family and work. ${ }^{(13)}$

Regarding the family income, it can be observed that most of the caregivers had a considered low income (up to two minimum salaries), that may be considered insufficient, since the disabled person often needs more financial support, which often creates an impact in family economic stability. This finding is supported by a research that identified a higher prevalence among those of socioeconomic class D (middle-low class). ${ }^{(14)}$

Regarding habits, most caregivers reported not to practice any form of regular physical activity, a factor that can be explained by the lack of time for self-care, because, according to the data collected in this study, most caregivers dedicated all period of the day to assist the children. Comparable prevalence was found in another study in which it was found that most caregivers had difficulties in leisure activities, causing social and professional damage, due to total dedication to the child. ${ }^{(10)}$ Makiyama (2004) ${ }^{(15)}$ found a prevalence similar to the one found on this study relating to the function of the caregivers who dedicates 24 hours/day to assist the child. Thus, the demand of care has great influence on the physical, psychological and social health of the caregiver, which leads to fatigue, isolation, overload and stress. ${ }^{(16)}$

Regarding quality of life, in a general way, an overall average scores slightly above the median (64.9) was found, presenting rather unsatisfactory. This result corroborates a study by Oliveira (2008) ${ }^{(2)}$, which states that, despite the unsatisfactory quality of life, the caregivers, even in the face of difficulties, find other forms to care, with the aim of providing a better life for their children. With regard to the domains, the "functional capacity" presented the highest score (79.0). Similar data was found in a study by Prudente (2010) ${ }^{(17)}$, in which the average value found in the first evaluation was 82.6 , with overall score $=66.9$. In another study it was found that mothers of children with cerebral paralysis have achieved global average of quality of life superior to 50 , and the functional capacity domain got the highest score ${ }^{(18)}$, similarly to this study. According to Ware (2000) ${ }^{(19)}$, functional capacity includes the ability of the caregiver to perform vigorous activities such as; climb several flights of stairs, walk several blocks, besides loading the child's 
Table 3. Mean and standard deviation of the domains of the SF 36 related to the caregivers. Paraíba. 2015

\begin{tabular}{lcccc}
\hline \multicolumn{1}{c}{ Domain } & Average & Standard Deviation & Minimum & Maximum \\
\hline Functional capacity & 79.9 & 19.6 & 30 & 100 \\
Limitation by physical aspects & 52.5 & 41.4 & 31 & 100 \\
Pain & 61.0 & 17.0 & 20 & 100 \\
General state of health & 62.3 & 21.0 & 20 & - \\
Vitality & 59.3 & 16.4 & - & 100 \\
Social aspects & 65.4 & 29.3 & 12 & 100 \\
Limitation by emotional aspects & 71.3 & 36.3 & - & 90 \\
Mental health & 67.3 & 18.2 & 7.7 & - \\
Global score & 64.9 & &
\end{tabular}

Table 4. Correlation of the sociodemographic profile with the domains of the SF-36. Paraíba. 2015

\begin{tabular}{|c|c|c|c|c|c|c|c|}
\hline \multirow{2}{*}{ Domains } & \multicolumn{7}{|c|}{ Sociodemographic Variables } \\
\hline & Age & $\begin{array}{l}\text { Number of } \\
\text { Children }\end{array}$ & $\begin{array}{c}\text { Time of } \\
\text { Dedication }\end{array}$ & Family Income & $\begin{array}{l}\text { Receiving } \\
\text { Benefits }\end{array}$ & Life Habits & Transfer \\
\hline Functional capability & 0.245 & 0.07 & 0.83 & 0.816 & 0.662 & 0.192 & 0.662 \\
\hline Limitation by physical aspects & 0.507 & 0.898 & 0.997 & 0.801 & 0.358 & 0.746 & 0.358 \\
\hline Pain & 0.73 & 0.911 & 0.754 & 0.956 & 0.199 & 0.437 & 0.199 \\
\hline General state of health & 0.729 & 0.686 & 0.199 & 0.584 & 0.628 & 0.638 & 0.628 \\
\hline Vitality & 0.621 & $0.012^{*}$ & 0.303 & 0.93 & $0.044^{*}$ & 0.761 & $0.044^{*}$ \\
\hline Social aspects & 0.368 & 0.299 & 0.356 & 0.33 & 0.121 & 0.499 & 0.121 \\
\hline Limitation by emotional aspects & 0.552 & 0.748 & 522 & 0.665 & 0.347 & 0.965 & 0.347 \\
\hline Mental health & 0.087 & 0.274 & 0.842 & 0.877 & 0.221 & 0.18 & 0.221 \\
\hline
\end{tabular}

*Significant Correlations, $\alpha<0,05$.

weight and moderate activities, such as climbing a flight of stairs or walking a block.

Some problems faced by caregivers, such as social exclusion, emotional and social isolation, depression, erosion in relationships, loss of perspective on life and others (20) may be associated with the restriction of possibilities of the caregiver having a better quality of life. ${ }^{(21)}$ Thus, the domain "vitality" got one of the lowest scores and showed significant correlation with some demographic data. This domain refers to the vigor and energy of the caregiver's performance that often manifests as exhaustion and fatigue. ${ }^{(19)}$ The results of this study, in relation to the vitality domain, corroborate with the study of Ciconelli et al (1999) ${ }^{(22)}$, in which it was identified that caregiver overload may reduce the quality of care and, consequently, can affect the health of the person receiving care. A study conducted in Turkey has highlighted the evidence that the quality of life, assessed by the SF-36 questionnaire, of primary caregivers of children with cerebral paralysis, compared to primary caregivers of children without cerebral paralysis, was significantly lower in the field "vitality", as well as in relation to the "general health" and "emotional aspects". (23)

The act of caring for the child with special needs already demands from the mother a greater support. Adding to this demand the care of another child, being the bearer of special needs or not, it demands more attention of these caregivers to the children, causing a more intense physical and emotional exhaustion. Therefore, according to the data analyzed, it can be said that the number of children significantly interferes with the quality of life, especially in the vitality of the caregivers. Sousa et al (2007) ${ }^{(24)}$ claim that aspects such as family relationships, housework and raising children makes the caregivers indulge themselves to these responsibilities, becoming a form of voluntary sacrifice, surpassing their own limits for the benefit of the welfare of the child and of the whole family. Therefore, the health team must turn to these caregivers in order to promote a better quality of life and maintain their health.

The inexistence of a benefit aid, presented by most caregivers, showed a statistically significant correlation with regard to their quality of life, specifically in the vitality domain. The finding may be explained by the low socioeconomic status of the study participants, causing a series of difficulties to ensure the appropriate needs of the child are satisfied, thus demanding a sacrifice from the caregiver to give this support. In another study, it was observed that some children receive benefits from the National Social Security Institute (INSS) due to the chronic nature of the disease, but this source of income was deemed insufficient. Thus, the authors state that the 
economic aspect interferes on the quality of life of children with cerebral paralysis, as well as the other family members, because the resources are not enough for the treatment of the child, and often families don't have income enough to even meet their daily needs. ${ }^{(25)}$

Another factor that proved to affect the quality of life of the caregivers was the way the transfer of the child is carried out. Although most have stated that they receive assistance, either partial or total, the dependence of the child to perform daily activities, causes an overload on these caregivers, that's a factor that causes physical and mental wear. Sales (2007) reported that the care dispensed to a family member who has a chronic disease results in feelings of overload or tension, and thus decrease the quality of life of the caregiver. ${ }^{(26)}$

\section{CONCLUSION}

The quality of life of the caregivers of children with neuromotor changes is compromised, mainly, on the domain of limitation by physical aspects. However, the vitality suffered interference statistically significant by the variables: number of children, receiving of benefits and kind of transfer with the child. Although the study did not prove that other variables, such as the time of care, kind of transportation, family income, among others, can present as predisposing factors that compromise the quality of life of the caregivers. This highlights the importance of specific policies regarding prevention, like orientation and, if needed, treatment for improvement of possible grievances.

\section{AUTHOR'S CONTRIBUTIONS:}

PMB RVPF EML NGL: Collect the data, conceived and designed the experiments SLSR MFAB AGCC MGRA: Review the literature, wrote and corrected the article NMGL: Guided the work, conceived and designed the experiments

\section{CONFLICTS OF INTEREST:}

There are no conflicts of interest.

\section{AUTHOR DETAILS}

${ }^{2}$ Universidade Federal da Paraíba (UFPB), João Pessoa, Paraíba (PB), Brazil.

${ }^{3}$ Program in science and technology, Universidade de Brasilia (UNB), Brasília (DF), Brazil.

${ }^{4}$ Laboratory of Kinesiotherapy and Manual Therapeutic Resources, Program in Physical Therapy, Universidade Federal de Pernambuco, Recife (PE), Brazil.

\section{REFERENCES}

1. Rago ALP. Aprendendo a Aprender Juntos: O Trabalho em Grupo no Atendimento a Crianças com Deficiência Visual e Deficiência Neuromotora. Constr. Psicopedag. 2009 Dez;17(15).

2. Oliveira MFS, Silva MBM, Frota MA, Pinto JMS, Frota LMCP, de Sá FE. Qualidade de vida do cuidador de crianças com paralisia cerebral. RBPS. 2008;275-280.

3. Sousa SCB, Pires AAP. Comportamento materno em situação de risco: mães de crianças com paralisia cerebral. Rev. Psicologia, Saúde \& Doença. 2003;4(1):111-130.

4. Carvalho JTM, Rodrigues NM, da Silva LVC, de Oliveira DA. Qualidade de vida das mães de crianças e adolescentes com paralisia cerebral. Rev. Fisioterapia em Movimento. 2010;23(3):389-397.
5. Vecchia RD, Ruiz T, Bocchi SCM, Corrente JE. Qualidade de vida na terceira idade: um conceito subjetivo. Rev. Brasileira de Epidemiologia. 2005;8(3):246-252.

6. Lucena LC, Lucena NMG, Aragão POR, Lemos, MTM. Perfil sociodemográfico e índice de qualidade de vida de cuidadores de pessoas com deficiência física. Fisiot.e Pesq. 2011;18(3):223-7.

7. Moretti GS, Moreira KA, Pereira, SR. Qualidade de vida dos cuidadores de crianças com paralisia cerebral da Amazônia Sul ocidental. Rev. Bras. Promo. Saúde, 2011;25(1):30-36.

8. Takiuti ME, Hueb W, Hiscock SB. Quality of life after surgical myocardial revascularization, angioplasty or medical treatment. Arq Bras Cardiol. 2007;88:537-44.

9. Lemos MCD, Miyamoto ST, Valim V, Natour J. Qualidade de vida em pacientes com osteoporose: correlação entre OPAQ e SF-36. Rev. Bras. Reumatol. 2006;46:323-8.

10. Almeida KM, Fonseca BM, Gomes AA, Oliveira MX. Fatores que influenciam a qualidade de vida de paralisados cerebrais. Fisioter Mov. $2013 \mathrm{abr} / j u n ; 26(2): 307-14$.

11. Westphal A, Alonso NB, da Silva TI, Azevedo AM, Caboclo LOSF, Garzon E. Comparação da qualidade de vida e sobrecarga dos cuidadores de pacientes com epilepsia por esclerose mesial temporal e epilepsia mioclônica juvenil. J Epilepsy Clin Neurophysiol. 2005;11(2):71-76.

12. Mugno D, Ruta L, D'Arrigo V, Mazzone L. Impairment of quality of life in parents of children and adolescents with pervasive developmental disorder. Health Qual Life Outcomes. 2007;5:22-30.

13. Ones K, Yilmaz E, Cetinkaya B, Caglar N. Assessment of the quality of life of mothers of children with cerebral palsy (primary caregivers). Neurorehabil Neural Repair. 2005;19(3):232-7.

14. Rocha AP, Afonso DRV, Morais LRS. Relação entre desempenho funcional de crianças com paralisia cerebral e qualidade de vida relacionada à saúde de seus cuidadores. Fisioter Pesq. 2008;15(3):292-7.

15. Makiyama TY, Battisttella LR, Litvoc J, Martins LC. Estudo sobre a qualidade de vida de pacientes hemiplégicos por acidente vascular cerebral e de seus cuidadores. Acta Fisiatr, 2004;11(3):106-109.

16. Alpino MAS, Valenciano PJ, Furlaneto BB, Zechim FC. Orientações de fisioterapia a mães de adolescentes com paralisia cerebral: abordagem educativa para o cuidar. Rev. Brasileira de Educação Especial. 2013;19(4):597-610.

17. Prudente COM, Barbosa MA, Porto CC. Relação entre a qualidade de vida de mães de crianças com paralisia cerebral e a função motora dos filhos, após dez meses de reabilitação. Rev. Latino-Am. Enfermagem. 2010;18(2):[08 telas].

18. Eker L, Tüzün EH. An evaluation of quality of life of mothers of children with cerebral palsy. DisabilRehabil. 2004 Dec;26(23):1354-9.

19. Jr Ware JE. SF-36 health survey update. Spine (Phila Pa 1976). 2000 Dec 15;25(24):3130-9.

20. Floriani CA. Cuidador familiar: sobrecarga e proteção. Secretaria de Saúde de Estado do Rio de Janeiro. Rev Bras Cancerologia. 2004;50(4):341-345.

21. A'Campo LEI, Spliethoff-Kamminga NGA. Caregiver education in Parkinson's disease: formative evaluation of a standardized program in seven European countries. Qual Life Res, Oxford. 2010;19:55-64

22. Ciconelli RM, Ferraz MB, Santos W. Tradução para a língua portuguesa e validação do questionário genérico de qualidade de vida SF-36. Rev. Bras. Reumatol. 1999;39:143-9.

23. Tuna $H$, Ünalan $H$, Tuna F, Kokino S. Quality of life of primary caregivers of children with cerebral palsy: a controlled study with Short Form-36 questionnaire. Dev Med Child Neurol. 2004;46:646-8.

24. Souza LM, Wegner W, Gorini MIPC. Educação em saúde: uma estratégia de cuidado ao cuidador leigo. Rev Latino-am Enferm. 2007;15(2):337-43.

25. Vasconcelos VM, Frota MA, Pinheiro AKB, Gonçalves MLC. Percepção de mães acerca da qualidade de vida de crianças com paralisia cerebral. Cogitare Enferm. 2010 Abr/Jun;15(2):238-44.

26. Sales E. Family burden and quality of life. Qual Life Res. 2003;12(Suppl 1):33-41. 